\title{
文字を併記した視覚シンボルによるメッセージの 意図理解に及ぼす文脈の効果
}

\author{
藤 澤 和 子*
}

\begin{abstract}
本研究の目的は，視覚シンボルとその意味を文字で併記したもので表現した発信者のメッセージを正 確に理解するために，受信者に与えられた文脈となる事前の予備知識が，どのような理解促進の効果を もつのかを明らかにすることである。大学生 96 名を被験者とした実験を実施した。刺激材料には文字を 併記した視覚シンボルで表記した 2 つ手紙文を用い, 日本語に解釈する課題を行った。各被験者は各 群 24 名からなる 4 群のいずれかに割りあてられた。4 群は, 文脈を与えなかった群 (NC 群), 発信者の 個人情報と受信者との関係を与えた群 ( $\mathrm{R}$ 群), 話題のキーワードを与えた群 ( $\mathrm{K}$ 群), $\mathrm{R}$ 群と $\mathrm{K}$ 群の両方の 情報を与えた群 (RK 群) であった。実験の結果, 2 課題に共通して, K 群と RK 群の 2 群の文脈がシン ボルによるメッセージの理解に効果があると考えられた。また, 文脈の内容により解釈に差が認められ, 文脈によって活性化されたスキーマが，メッセージの解読内容に大きく影響していることが考察された。 キーワード：文字を併記した視覚シンボル, 文脈, スキーマ, コミュニケーション, 伝達意図
\end{abstract}

\section{問題と目的}

視覚シンボルは, 音声言語や文字が十分に使えない 障害者の補助代替コミュニケーション手段として，障 害児教育や言語臨床場面で活用されている。視覚シン ボルは，手話やサインなどの他の補助代替手段に比べ て, 意味することがわかりやすく理解するための学習 負担が少ない, 視覚的な持続性があるため記憶負担が 少ない, 1 回の指さしで 1 語彙を示すことができるた め運動負担が少ないという利点がある。そのため, 肢 体不自由, 知的障害, 自閉症の人への適用の成果が多 く報告されている。また，母語の違いに拘束されない 国際性をもつため, 外国人児童とのコミュニケーショ ンで活用した事例（藤澤·井上, 2000a）の成果も報告され ている。近年では, ユニバーサルデザインとして, 高 齢者や一般の人にもわかりやすさの利点が生かされる 動向がある（藤澤, 2004）。

本研究で使用する日本版 PIC (Pictogram Ideogram Communication 省略) は, 1980 年にカナダの言語聴覚士 である Maharaj が開発し, 1995 年に日本版(藤澤・井上・ 清水・高橋, 1995) が発表された。その後, シンボル数を 増やして, 現在は 1071 語の名詞, 動詞, 形容詞, 副詞 などの複数の品詞で構成されている(藤澤・井上, 2000b)。品詞があるため, 主部と述部から成る文を作る ことができる語彙の体系になっている。絵柄は黒地の

* 京都府立龖学校
背景に対象物を白抜きにしたシルエット像であり，こ の特徵によって認識が速くて間違いが少ないシンボル であるという実験結果が報告されている（北神・山縣・室 井, 2002)。通常, PIC シンボルはシンボルの下に文字て 名称を併記してある。使用方法は発信者と受信者が, 発信者に必要なシンボルを入れたコミュニケーション ボードやブックをはさんで対面し，発信者が伝えたい ことばを示すシンボルを指さして伝達する。受信者は, 指さされたシンボルを話しことばでフィードバックし て, 発信者が伝達したい意図を確認しながらコミュニ ケーションをすすめる。例えば発信者が「食べる」と いう 1 つのシンボルを指さして何かを伝えた時,「食べ たいですか，食べることが好きということですか」な どと, 話しことばでシンボルの意味を確認しながら意 図を読み取っていく。最近では, 直接的なコミュニケー ション場面に限らず, 遠隔コミュニケーションのツー ルとして, シンボルを使ったメールシステムが開発さ れ(清田・中山・藤澤・井上, 2004), PIC シンボルで作った 文章をメールとして送信することもできるようになっ た。

シンボルの名称は, 基本的には各シンボルに 1 つ付 けられている。実際のコミュニケーション場面では, 例えば，［幸せ］（以降,シンボルは［］で記す）を，［う れしい］[楽しい]などと，既存の名称に類似する概念 で, 発信者がわかりやすい名称に変更して使用される ことがよくあり，それは使用者のシンボルの理解を促 すためには有効な手だてであることが示されている 
(藤澤, 2000)。シンボルで伝達するための特別な文法規 則はなく, 通常に併用して用いられる話しことばと同 様の語順で並べていく。1 語発話の段階の人は，1つ のシンボルで伝達し, 語連鎖ができる人は, シンボル をいくつか並べた文章で伝える。例えば,「みかんがほ しい」と伝えたいとき，[みかん] のシンボルだけを指 さす場合，[みかん］[ほしい], あるいは[ほしい］［み

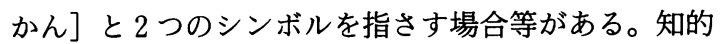
な遅れがある人には，このような規則のない使用方法 が, 使いやすいと考えられる。

しかし, 一方で, 文字を併記したシンボルは独立語 のみの表現で, 助詞や助動詞, 接続詞がないことや, シンボルで表現できる語彙数に限界があることによっ て, 文法的に完全な表記は困難である。また, 発信者 のほとんどの人が文字を読むことができないため, シ ンボルに併記された文字の名称通りに, 発信者が使用 するとは限らない。受信者にとって, 文字の表記はシ ンボルの理解を助けるが, それは十分であるとはいえ ない。さらに障害者が使う場合, 運動能力や知的能力 の障害によって, 伝達意図のすべてをシンボルで表す ことができない場合も多くある。このようにシンボル は文字が併記されていても, 文法的にも, 発信者の能 力によっても, 完全な文章表記が難しい記号である。 また，知的障害のある人が，自分の伝達したい意図が 相手に伝わらない時に, 自分から相手に説明を加える などの行動を取ることは難しい。

そのため, 臨床場面では, 受信者が, 障害者本人の 伝達内容を理解しよう, 思いを聞こうとする姿勢を 持っていること（広川・吉田, 1985 ; 塚原, 2001) や, 話題 となるテーマについて, 事前に情報を得ることが重要 であることが報告されている（土井, 2001）。このように シンボルでコミュニケーションを十分にとるためには， 聞き手となる人の臨床経験やシンボルを使用した経験, 話し手との人間関係の深まりが必要だと考えられる。

しかし，学校や施設などでは，年度によって担任や 担当者が代わるという事情があり，継続したコミュニ ケーション関係をもつことが難しい現実がある。新し い担当者が，シンボルを使ったことがない人や発信者 と初対面である場合, 初めから十分にコミュニケー ションをとることは難しい。そのため, 発信者は, 伝 達意図が理解されず, 相互的な関係が不成立に終わる 経験をもつことになる。このような経験は, コミュニ ケーション意欲やシンボルを使用する意欲を減退させ ることにつながる。さらに，シンボル使用者が人間関 係を拡げるためには, 日常生活で出会う複数の人たち
とシンボルを使ったコミュニケーションの機会を積極 的に設けていく必要がある。その場合も, 初対面の人 やシンボルの未経験者が伝達相手になる可能性が高く, 全く発信者についての情報をもたずに，コミュニケー ションをするケースもある。Augmentative and Alternative Communication（補助代替コミュニケーション）の 使用効果を論じた Glennen \& DeCoste（1997）は，そ の中のいくつかの項目にパートナーとの自発的相互作 用の増加, 相互交渉が不成立に終わる数の減少, パー トナーの数の増加を上げている。

本研究では，コミュニケーションパートナーの交代 の問題やパートナーの増加を目指す場合に,できるだ け相互交涉の不成立を減少させ，初対面や未経験者と のコミュニケーション効果を高めるための方策の一つ として, 文脈の効果について考えたい。臨床現場では, 新しくパートナーになる人へ発信者についての背景情 報の引き継ぎが行われることが多い。経験的には引き 継ぎがコミュニケーションの不成立を減少させるため に有効であると考えられているが, どのような情報を 伝えると効果的であるのか, さらにどの程度の有効性 があるのかについては, 経験に負うところが大きく, 明確に検証はされていない。生活場面で新しいパート ナーと出会う場合でも, 初対面のパートナーに回りの 人が事前に何を伝えればコミュニケーションがとりや すいのか，明らかにはされていない。

そこで, 本研究では，2つの事例で記録された文字 を併記したシンボルによるメッセージを材料として用 い, 文脈となる事前の予備知識が, 初対面や未経験者 のメッセージの理解に, 効果があるかどうか, どのよ うな文脈が効果的であるかについて, 実験の手法で検 証する。さらに, 文脈がシンボルのメッセージの解釈 過程において，どのように影響を及ぼすのかという認 知処理についても考察し, 文脈効果の利用方法を考え る。

材料の 1 つは, ボリビアから 11 歳の時に, 家族とと もに来日した日本語が全く使えない健常の女子（藤澤・ 井上, 2000a）のメッセージである。2 つめは, 重症心身 障害者施設に入所している脳性麻痺の女性（藤澤, 2001） のメッセージである。彼女は障害によって音声言語は 全く表出できないが, 絵画語彙発達検査の結果では, 理解語彙は 8 歳 2 ヶ月の段階にある。この 2 事例の メッセージを材料にした理由は， 2 人とも日本語の話 しことばは表出できないが，シンボルを使用する対象 者の中では知的に高くて内言があり, 本人たちの伝達 したい内容と意図が明確であったことである。 
先行研究としては, 正確に理解することが難しいと 思われる複雑な内容のテキストを実験材料として, 難 解な情報を理解し記憶するうえでの文脈の影響に焦点 をあてた Bransford \& Johnson (1972) の有名な 2 つの 実験がある。「文脈」とは「事前に与えられた予備知識」 という意味を示している。1つめの「the Balloon Passage」とよばれる実験では, 被験者を, 事前にテキス トが表現する場面を絵で見せた群, 見せていない群, テキストを読んだ事後に見せた群と事前に部分的に絵 を見せた群に分けて,群別に難解なテキストの理解度 を調査した。その結果, 圧倒的に事前に絵を見せた被 験者のテキスト内容の理解と記憶が高くなったことが 示されている。2つめの「Washing Clothes」の実験 でも, 何について書かれているのかがわかりにくい難 解なテキストを提示して被験者に解釈を求めた。 Washing Clothes というキーワードを事前に与えた群 と与えなかった群に分けて, 理解度を調査した結果, 事前に与えた群の方が, テキスト内容の理解と記憶が よかったことが報告されている。2つの実験から，難 解なテキストの理解と記憶という人間の情報処理過程 において, 事前に与えられた文脈が大きく影響するこ とが示された。

本実験では, 文脈は材料を理解する上で有用であっ たと思われる「発信者の個人情報と受信者との関係」 および「話題のキーワード」を選んだ。初対面や未経 験者のメッセージの理解について実験するため, シン ボルを使ったコミュニケーション経験のない大学生を 被験者とした。彼らを文脈を与えなかった群（NC群： No Context), 発信者の個人情報と受信者との関係を与 えた群 (R 群: Relation), 話題のキーワードを与えた群 (K 群 : Keyword), 発信者の個人情報と受信者との関係 および話題のキーワードの両方を与えた群（RK群： Relation+Keyword)の 4 群に分けた。実際の指導場面で は, 発信者のメッセージがわからないときには, 質問 などのやりとりをして, 発信者のシンボルによる返答 やその時の表情, 動作などの様々な情報を頼りに意図 理解をすすめるが, 本研究では, 文脈だけの影響を客 観的に捉えることを目的とするため, メッセージは, 発信者が伝達した内容だけを取り出した手紙文という 方法を用いた。

\section{方法}

\section{被験者}

20 歳〜28 歳の範囲で平均年齢 21 歳。日本の大学生 と大学院生で男子 35 名, 女子 61 名の 96 名であった。
被験者を $\mathrm{NC}$ 群, R 群, $\mathrm{K}$ 群, $\mathrm{RK}$ 群の 4 群に分け, 各 群を 24 名で構成する。全員が健常者であり, 調査以前 にシンボルを見た経験はない。

\section{材料}

文字を併記したシンボルの 2 つの材料は, 課題 1 を 「海外からの転校」, 課題 2 を「戦争中の思い出」とし た(Appendixを参照。ただし課題用紙では,アルファベットで分 けられた項目は, 1 つの文として1 行につながって表示され, 正解 例は示されていない)。課題 1 は, 事例 1 のメッセージを材 料としたものであり, 学校の言語指導室において家庭 や学校での状況や気持ちを聞く目的で筆者が質問をし て, それに対象者が回答した内容である。課題 2 は, 事例 2 のメッセージを材料としたものであり，自分の 生い立ちを語りたいという本人の意思に対応したもの で, 病院の指導室において, 担当する言語聴覚士が, 伝達された内容を本人に確認をとりながら書き留めた ものである。2 つの材料は, 単文や複文, 重文による 10 の文から構成され, 主部と述部から成る命題を 1 項 目とすると, 課題 1 は 13 項目, 課題 2 は 16 項目とな る。Appendix で, 複数の項目で構成される文につい て, 項目をアルファベットで表示した。シンボルの下 に併記した文字の名称は, 日本 PIC 研究会で付けられ た日本語名 (清水, 2003) である。手紙 2 題はいずれも実 際に伝達された内容をもとにして若干の加筆修正を施 したものである。 2 者間の応答場面でメッセージの伝 達が行われたので, 私という主語をシンボルで示すこ とはなく, 実際のコミュニケーションが進展した。そ のため, 材料として提示された文字を併記したシンボ ルの手紙には，私という主語が省略されている。

\section{手続き}

材料に示した文字を併記したシンボルの手紙 (Appendix を参照) と教示と文脈を課題 1 と 2 ごとに記 載したA 3 の用紙 2 枚を, 被験者に手渡し, 2 題に回 答することを求めた。文脈は, Table 1 に示すように 課題 1 と 2 につて, 4 群ごとに異なる内容が書かれ た用紙を配布して, 課題を実施している間, 用紙を参 照できるようにした。例えば, 課題 1 の NC 群には,

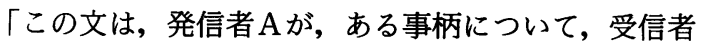
Bにシンボルを使って伝えた内容です」, RK 群には, $\lceil 11$ 歳の女子の生徒が, 海外からの転校について, 学 校の先生にシンボルを使って伝えた内容です」と, 用 紙に記載し伝えた。問題には,「シンボルの文は, 発信 者が伝えた順番にシンボルが並んでいるが, 主語, 目 的語, 述語などがあるとは限らず, 必要なことばのシ ンボルが省略されていることもあり, 文法的に完全で 
Table 14 群に与えた文脈の内容と 2 課題における具体的内容

\begin{tabular}{|c|c|c|c|c|}
\hline 群 & NC 群 & $\mathrm{R}$ 群 & K 群 & RK 群 \\
\hline 文脈 & 文脈なし & $\begin{array}{l}\text { 発信者に関する情報（発信者の } \\
\text { 年齢・性別・所属） } \\
\text { ○受信者との関係 } \\
\end{array}$ & ネ話題のキーワード & $\begin{array}{l}\text { 発信者に関する情報 } \\
\text { ○受信者との関係 } \\
\star \text { 話題のキーワード }\end{array}$ \\
\hline 課題 1 & なし & $\begin{array}{l}\text { 11歳の女子の生徒 } \\
\text { ○学校の先生 }\end{array}$ & ネ海外からの転校 & $\begin{array}{l}11 \text { 歳の女子の生徒 } \\
\text { ○学校の先生 } \\
\star \text { ネ海外からの転校 } \\
\end{array}$ \\
\hline 課題 2 & なし & $\begin{array}{l}65 \text { 歳の女性の肢体不自由の施設 } \\
\text { 入所者 } \\
\text { ○指導員 }\end{array}$ & ネ戦争中の思い出 & $\begin{array}{l}65 \text { 歳の女性の肢体不自由の施設 } \\
\text { 入所者 } \\
\text { ○指導員 } \\
\text { ネ戦争中の思い出 }\end{array}$ \\
\hline
\end{tabular}

ネは，文脈の内容と対応した具体的内容

あるとは限らない。シンボルの呼び名は表記されたも のと同じ呼び名であるとは限らない」と記載されてい た。各自でシンボルの手紙と教示と文脈を読んで, シ ンボルで表記された手紙を日本語の書きことばに解釈 して記述すること，1行に並ぶシンボルは，1 つの文 を表現していることを口頭で伝えた。時間制限は特に 設けず，できた時点で提出を求めた。所要時間はおよ そ 15 分〜30 分程度で, 被験者は性別や専攻などの条 件が特定の群に集中しないように配慮した。

\section{結果}

\section{得点化の手続き}

発信者が指さした文字を併記したシンボルについて， その意味や伝達意図を受信者が発信者に日本語で確認 をとり表記した文を正解例 (Appendix を参照) とした。 それを基準にして, 各項目について, 以下に示す 4 点 満点の 5 段階による得点化がなされた。 4 点：「主部 と述部の意味がほほ正しく, 話の内容は文脈上大きく 間違っていない」。 3 点：「主部と述部のいずれかに問 題はあるが, 話の内容は文脈上大きく間違っていな い」。 2 点：「主部と述部のいずれにも問題があるが, 話の内容は文脈上大きく間違っていない」あるいは「主 部と述部の意味はほほ正しいが, 話の内容が文脈上大 きく逸脱している」。1点：「主部と述部のいずれかに 問題があり, 話の内容が文脈上大きく逸脱している」。 0 点：「主部と述部のいずれにも問題があり, 話の内 容が文脈上大きく逸脱している」。

ただし，主語にあたるシンボルが省略されている文 については, 回答の文脈が正しい場合は, 主語がなく ても主部が正しいと解釈して得点化した。シンボルの 名称は, 例えば,「冷たい」ということばを,「寒い」 という類義語で解釈した場合も，正解とした。

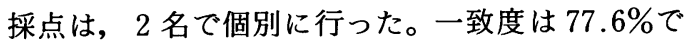

あった。一致しない項目は，2人で一致するまで吟味 して採点した。

\section{課題 1 についての分析結果}

\section{1) 平均得点}

4 群の 1 項目あたりの平均得点を Table 2 に, 4 群 の各項目における平均得点を Figure 1 に示す。Table 2 に示すように, $\mathrm{NC} \cdot \mathrm{R} \cdot \mathrm{K} \cdot \mathrm{RK}$ 群の順に平均得点が 高くなる結果が得られた。

分散分析の結果は, 項目の主効果が, 統計的に有意 であることが示された $(F(12,1104)=27.024, p<.001)$ 。ま た，群による主効果も，統計的に有意であることが示 された $(F(3,92)=7.866, p<.001)$ 。さらに, 項目と群の 交互作用についても, 統計的に有意であることが示さ れた $(F(36,1104)=3.184, p<.001)$ 。すなわち， 4 群それ ぞれの得点の分布は, 13 個の項目によって, 異なるパ ターンを示したものといえる。

課題 1 の各項目について多重比較 (Tukey の HSD) を 行い, 4 群間の下位分析を行った結果, Table 3 に示 すように 1-1，1-4 a, 1-4 b, 1-6 の項目において，NC 群と, R, K, RK のいずれかの群間に有意差が認めら

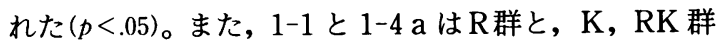
の間, 1-7 は R 群と $\mathrm{K}$ 群間に有意差が認められた $(p<$ .05)。一方で, 1-8 b は, 4 群間に有意差がなくかつ得点 が低い回答の項目であった。

Table 2 課題 1 と 2 における 4 群の 1 項目あたりの 平均得点

\begin{tabular}{ccccc}
\hline 群 & $\mathrm{NC}$ 群 & $\mathrm{R}$ 群 & $\mathrm{K}$ 群 & $\mathrm{RK}$ 群 \\
\hline 課題 1 & 1.10 & 1.35 & 1.62 & 1.97 \\
\hline 課題 2 & 1.02 & 1.58 & 1.72 & 1.82 \\
\hline 数值は小数点第 2 位で四捨五入 & &
\end{tabular}




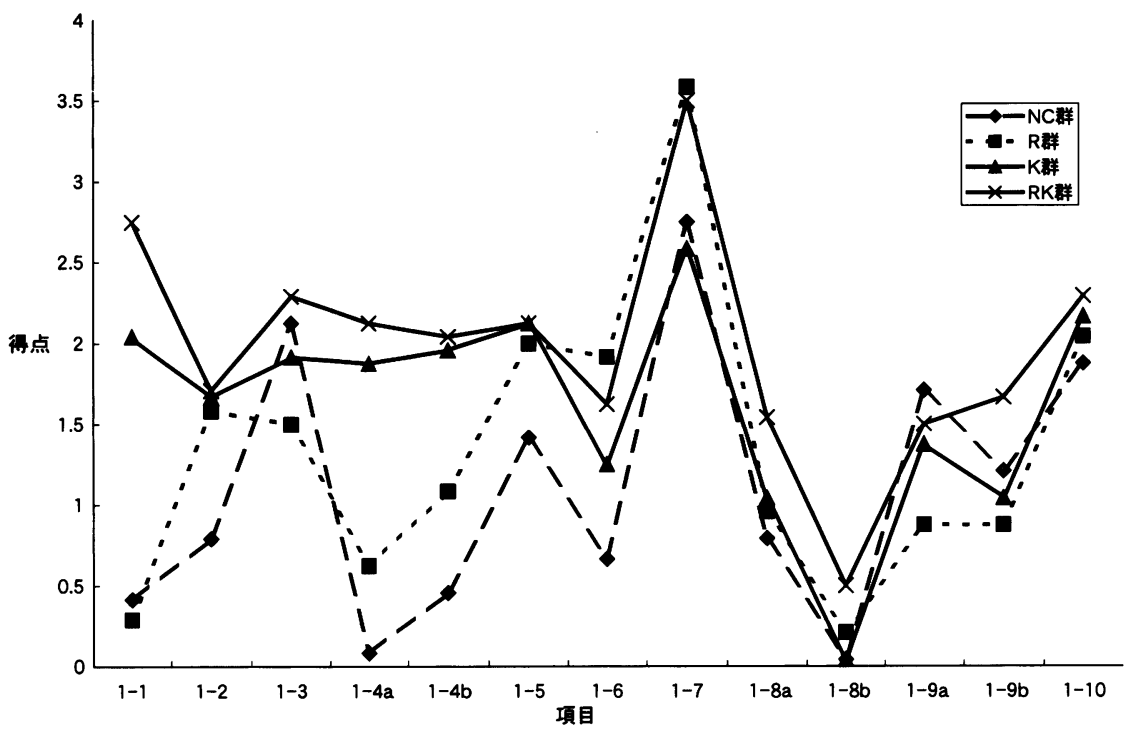

Figure 1 課題 1 の 4 群の各項目における平均得点

Table 3 課題 1 と 2 における NC 群と 有意差がある群の項目

\begin{tabular}{lccc}
\hline & NC-R & NC-K & NC-RK \\
\hline $1-1$ & & $\bullet$ & $\bullet$ \\
$1-4 \mathrm{a}$ & & $\bullet$ & $\bullet$ \\
$1-4 \mathrm{~b}$ & & $\bullet$ & $\bullet$ \\
$1-6$ & $\bullet$ & $\bullet$ & \\
$2-2$ & & $\bullet$ & $\bullet$ \\
$2-4 \mathrm{a}$ & & $\bullet$ & $\bullet$ \\
$2-6$ & & $\bullet$ \\
$2-7 \mathrm{a}$ & $\bullet$ & $\bullet$ & $\bullet$ \\
$2-8 \mathrm{a}$ & $\bullet$ & $\bullet$ & $\bullet$ \\
$2-8 \mathrm{c}$ & $\bullet$ & $\bullet$ & $\bullet$ \\
$2-8 \mathrm{~d}$ & $\bullet$ & $\bullet$ & $\bullet$ \\
$2-10 \mathrm{a}$ & & $\bullet$ & \\
\hline
\end{tabular}

有意差のある群間を示す

\section{2 ）有意差のあった群の回答例}

Table 3 で示した項目の 4 群について，2 名以上の 被験者が同じ解釈をした回答例と人数を Table 4 に示 す。

各項目について，有意差のあった群の回答例を示す。 1-1「私は家族で日本に来た」という正解例に対し，RK 群の 14 名, K群の 7 名が答えた「家族といっしょに来 た」「家族といっしょに日本に来た」「家族で日本に来 た」という回答例は，話の内容や主部，述部の意味が 正解例とほほ同じであったが，NC 群の 16 名，R群の 11 名は, 主部や述部や内容が正解例と異なる「家族が
来る」「家族が自分に会いに来る」などという解釈をし た。1-4 a「私は日本語が話せない」という正解例に対 して, RK 群の 12 名, K 群の 9 名が答えた「話すこと ができない」「ことばがわからない」「日本語を話せな い」という回答例は，文脈上で正解例とほほ同じ内容 を示し, NC 群の 9 名, K群の 5 名は, 正解例と異なる 「話をしない」「話したくない」「話すのをやめる」と 回答した。1-4b「座っていた」という正解例に対し て, RK 群の 8 名と K群の 4 名が答えた「座っていた」 「座っているだけでした」という回答例は，正解例と ほほ同じ主部，述部と内容を示し，NC 群の 10 名は, 「座ってください」「座りなさい」という正解例と異な る解釈をした。1-6「私は男の子とけんかをした」は， $\mathrm{R}$ 群の 8 名が,「男の子とけんかをした」「少年とけん かをした」と，正解例と同じに私を主部と解积する回 答を示し, NC 群 11 名は, 男の子を主部と解釈する「男 の子がけんかをした」などの回答を示した。

\section{課題 2 についての分析結果}

\section{3 ) 平均得点}

4 群の 1 項目あたりの平均得点を Table 2 に， 4 群 の各項目における平均得点を Figure 2 に示す。Table 2 に示すように, $\mathrm{NC} \cdot \mathrm{R} \cdot \mathrm{K} \cdot \mathrm{RK}$ 群の順に平均得点 が高くなる結果が得られた。

分散分析の結果は, 項目の主効果が, 統計的に有意 であることが示された $(F(15,1380)=33.044, p<.001)$ 。ま た，群による主効果も，統計的に有意であることが示 
Table 4 課題 1 における NC 群と有意差がある群の項目の回答例

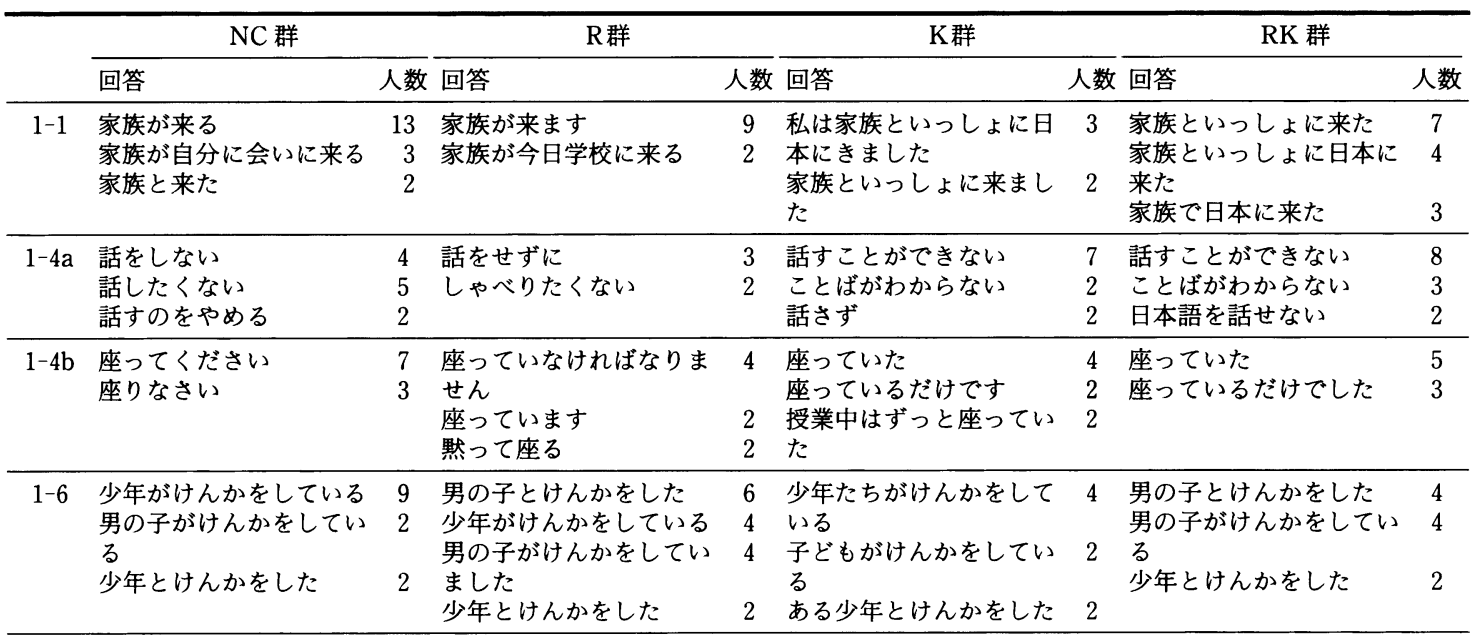

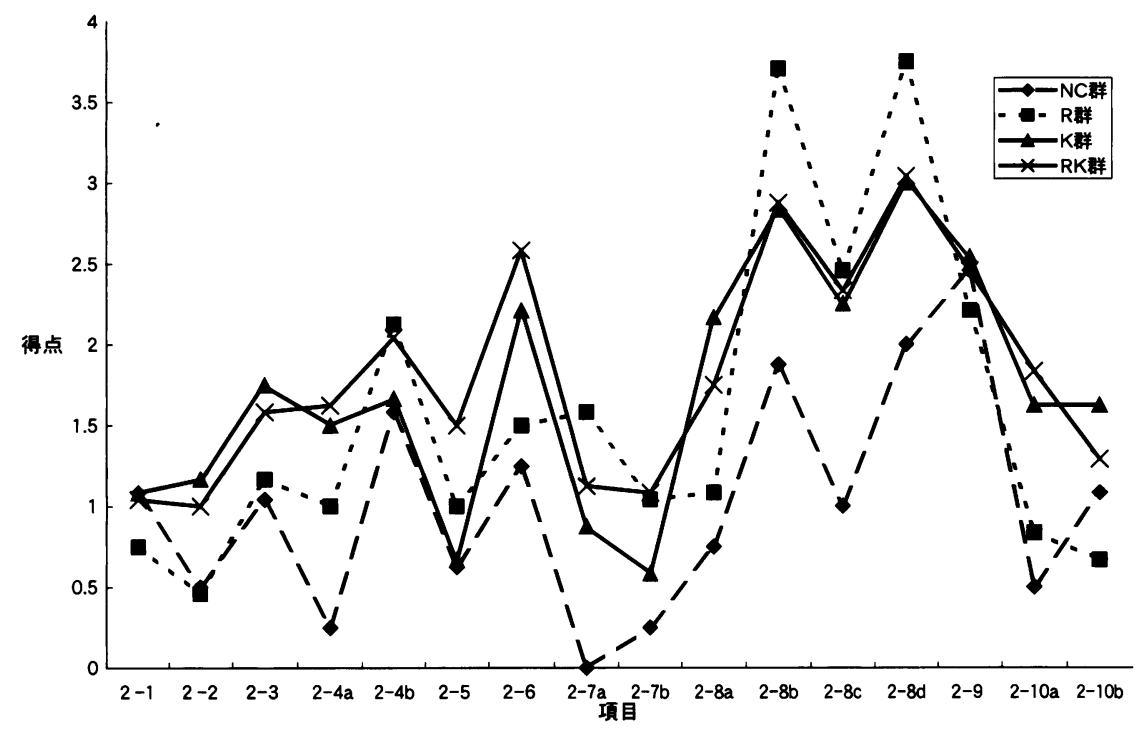

Figure 2 課題 2 の 4 群の各項目における平均得点

された $(F(3,92)=10.288, p<.001)$ 。さらに，項目と群の 交互作用についても，統計的に有意であることが示さ れた $(F(45,1380)=2.526, p<.001)$ 。すなわち， 4 群それ ぞれの得点の分布は, 16 個の項目によって, 異なるパ ターンを示したものといえる。

課題 2 の各項目について多重比較を行い，4群間の 下位分析を行った結果, Table 3 に示すように，2-2, 2-4 a，2-6，2-7 a，2-8 a，b，c，d，2-10 a の項目に おいて，NC 群と， R，K，RKのいずれかの群間に有 意差が認められた $(p<.05)$ 。また，2-2, 2-8 a の項目
で， R 群と K 群間に有意差が認められた $(p<.05)$ 。一方 で，2-1，2-7 b は，4 群間に有意差がなくかつ得点が 低い回答の項目であった。

\section{4 ) 有意差のあった群の回答例}

Table 3 で示した項目の 4 群について, 2 名以上の 被験者が同じ解积をした回答例と人数を Table 5 に示 す。

各項目について，有意差のあった群の回答例を示す。 2-2「兵隊さんは家で寝ていた」は，K群で 2 名が,「兵 士が家で寝ていた」と正解例と同じ回答をした。NC 群 
Table 5 課題 2 における NC 群と有意差がある群の項目の回答例

\begin{tabular}{|c|c|c|c|c|c|c|c|c|}
\hline & $\mathrm{NC}$ 群 & & R群 & & K群 & & RK 群 & \\
\hline & 回答 & 人数 & 回答 & 人数 & 回答 & 人数 & 回答 & 人数 \\
\hline $2-2$ & $\begin{array}{l}\text { 男が家で寝ている } \\
\text { 男は帰ってねるだけだ } \\
\text { 父親は家で葠ている } \\
\text { 兄は家に㷌ってきたらす } \\
\text { ぐに誛る }\end{array}$ & $\begin{array}{l}4 \\
2 \\
2 \\
2\end{array}$ & $\begin{array}{l}\text { 弟は家で寝ている } \\
\text { 夫は家で葠ている }\end{array}$ & $\begin{array}{l}3 \\
3\end{array}$ & $\begin{array}{l}\text { 男が家で寝る } \\
\text { 男が家に慢って寝る } \\
\text { 私は家で寝ていた } \\
\text { 兵士が家で寝ていた } \\
\text { むすこは家に帰ってきて } \\
\text { 眠りについた }\end{array}$ & $\begin{array}{l}5 \\
3 \\
2 \\
2 \\
2\end{array}$ & $\begin{array}{l}\text { 男が家で寝る } \\
\text { 父は寝込んでいました } \\
\text { 父は家で寝ていた }\end{array}$ & $\begin{array}{l}5 \\
2 \\
2\end{array}$ \\
\hline $2-4 a$ & $\begin{array}{l}\text { 仕事をし過ぎる } \\
\text { 仕事を失う } \\
\text { 過労死する } \\
\text { 仕事ができない }\end{array}$ & $\begin{array}{l}4 \\
3 \\
2 \\
2\end{array}$ & $\begin{array}{l}\text { 仕事ができない } \\
\text { 私はもう仕事をすること } \\
\text { ができず } \\
\text { 仕事もない } \\
\text { 主人は仕事をやめた }\end{array}$ & $\begin{array}{l}3 \\
2 \\
\\
2 \\
2\end{array}$ & $\begin{array}{l}\text { 仕事ができない } \\
\text { 仕事もなく } \\
\text { 働かずに } \\
\text { 戦死はつらい }\end{array}$ & $\begin{array}{l}9 \\
4 \\
3 \\
2\end{array}$ & $\begin{array}{l}\text { 仕事をすることができな } \\
\text { い } \\
\text { 仕事がなく } \\
\text { 仕事中に } \\
\text { 仕事をやめた }\end{array}$ & $\begin{array}{l}3 \\
2 \\
2 \\
\end{array}$ \\
\hline $2-6$ & $\begin{array}{l}\text { 姉は都会にでて働いてい } \\
\text { る } \\
\text { 姉は町にでて働いていた } \\
\text { 姉はオフィスで働いてい } \\
\text { る }\end{array}$ & $\begin{array}{l}8 \\
2 \\
2\end{array}$ & $\begin{array}{l}\text { 姉は町で働いている } \\
\text { 私の姉は町で仕事をして } \\
\text { いました } \\
\text { 私の姉は都会で働いてい } \\
\text { ます }\end{array}$ & $\begin{array}{l}5 \\
3 \\
3\end{array}$ & $\begin{array}{l}\text { 姉は町で仕事をしている } \\
\text { 姉は仕事をするために町 } \\
\text { にでた } \\
\text { 姉は町に仕事をしに出て } \\
\text { いた } \\
\text { 姉は工場で働いている }\end{array}$ & $\begin{array}{l}5 \\
3 \\
2\end{array}$ & $\begin{array}{l}\text { 姉は町で働いていた } \\
\text { 姉は町に働きに行った } \\
\text { 姉は出稼ぎに行った } \\
\text { 姉は町にでて働いた }\end{array}$ & $\begin{array}{l}5 \\
5 \\
3 \\
2\end{array}$ \\
\hline $2-7 a$ & $\begin{array}{l}\text { 歩かない } \\
\text { 歩くのがいや } \\
\text { 歩きでは帰れない } \\
\text { 歩かなくてもよい }\end{array}$ & $\begin{array}{l}6 \\
3 \\
2 \\
2\end{array}$ & $\begin{array}{l}\text { 家まで歩けない } \\
\text { 私は歩くことができない } \\
\text { 歩けない } \\
\text { 私はうまく歩けません }\end{array}$ & $\begin{array}{l}4 \\
3 \\
2 \\
2\end{array}$ & $\begin{array}{l}\text { 歩いて家まで帰らない } \\
\text { 歩けない } \\
\text { 私は歩くことができない } \\
\text { 歩くのがいや }\end{array}$ & $\begin{array}{l}3 \\
3 \\
2 \\
2\end{array}$ & $\begin{array}{l}\text { 歩くことができない } \\
\text { 帰らない } \\
\text { 歩いて帰らなかった }\end{array}$ & $\begin{array}{l}6 \\
3 \\
2\end{array}$ \\
\hline $2-8 a$ & $\begin{array}{l}\text { 姉がうちに泊まりに来る } \\
\text { 姉は寝こんでいて見舞い } \\
\text { に来てくれる人がいる } \\
\text { 姉が病気で友だちが来る }\end{array}$ & $\begin{array}{l}2 \\
2 \\
2\end{array}$ & $\begin{array}{l}\text { 姉が来た } \\
\text { 姉が泊まりにくる } \\
\text { 姉が私が寝るとき来てく } \\
\text { れる }\end{array}$ & $\begin{array}{l}5 \\
4 \\
3\end{array}$ & $\begin{array}{l}\text { 姉が寝に帰ってくる } \\
\text { 姉が帰ってくる }\end{array}$ & $\begin{array}{l}4 \\
4\end{array}$ & $\begin{array}{l}\text { 姉が帰って来る } \\
\text { 姉が泊まりに来る }\end{array}$ & $\begin{array}{l}6 \\
3\end{array}$ \\
\hline $2-8 b$ & $\begin{array}{l}\text { うれしかった } \\
\text { 幸せです } \\
\text { 喜ぶ }\end{array}$ & $\begin{array}{l}9 \\
5 \\
2\end{array}$ & $\begin{array}{l}\text { うれしかった } \\
\text { 幸せです }\end{array}$ & $\begin{array}{r}19 \\
2\end{array}$ & $\begin{array}{l}\text { うれしかった } \\
\text { 幸せです }\end{array}$ & $\begin{array}{r}12 \\
3\end{array}$ & $\begin{array}{l}\text { うれしかった } \\
\text { 幸せです }\end{array}$ & $\begin{array}{r}14 \\
2\end{array}$ \\
\hline $2-8 c$ & $\begin{array}{l}\text { 州ってしまう } \\
\text { 行ってしまう }\end{array}$ & $\begin{array}{l}3 \\
2\end{array}$ & $\begin{array}{l}\text { 帰ってしまう } \\
\text { わかれる }\end{array}$ & $\begin{array}{r}13 \\
2\end{array}$ & $\begin{array}{l}\text { 行ってしまう } \\
\text { 䚻ってしまう } \\
\text { 仕事に出かける }\end{array}$ & $\begin{array}{l}7 \\
4 \\
2\end{array}$ & $\begin{array}{l}\text { 帰ってしまう } \\
\text { 出て行く } \\
\text { 行ってしまう } \\
\text { 戻る }\end{array}$ & $\begin{array}{l}4 \\
4 \\
2 \\
2\end{array}$ \\
\hline $2-8 d$ & $\begin{array}{l}\text { 悲しい } \\
\text { さみしかった }\end{array}$ & $\begin{array}{l}7 \\
4\end{array}$ & $\begin{array}{l}\text { 悲しかった } \\
\text { さみしかった }\end{array}$ & $\begin{array}{r}18 \\
5\end{array}$ & $\begin{array}{l}\text { 悲しかった } \\
\text { さみしかった } \\
\text { つらかった }\end{array}$ & $\begin{array}{r}11 \\
3 \\
2 \\
\end{array}$ & $\begin{array}{l}\text { 悲しい } \\
\text { さみしかった }\end{array}$ & $\begin{array}{r}13 \\
2\end{array}$ \\
\hline $2-10 a$ & $\begin{array}{l}\text { ラジオを聞いた } \\
\text { 家族の悲報を聞いた } \\
\text { ラジオがない }\end{array}$ & $\begin{array}{l}7 \\
4 \\
2\end{array}$ & $\begin{array}{l}\text { ラジオで家族の話になる } \\
\text { ラジオを聞くと家族が恋 } \\
\text { しくなる } \\
\text { 家族のことが思い出され } \\
\text { る }\end{array}$ & $\begin{array}{l}3 \\
2 \\
2\end{array}$ & $\begin{array}{l}\text { ラジオで終戦の放送を聞 } \\
\text { いた } \\
\text { 玉音放送を聞いた } \\
\text { ラジオから家族の不幸を } \\
\text { 知らせる放送 } \\
\text { ラジオを聞くと家族を思 } \\
\text { い出す }\end{array}$ & $\begin{array}{l}2 \\
2\end{array}$ & $\begin{array}{l}\text { 終戦の知らせを聞いた } \\
\text { 玉音放送を聞いた } \\
\text { ラジオを聞いた } \\
\text { 家族の訃報を聞いた }\end{array}$ & $\begin{array}{l}7 \\
3 \\
3 \\
2\end{array}$ \\
\hline
\end{tabular}

の 6 名と R 群の 6 名は，述部だけ正しい回答をした。 2-4 a 「兵隊さんは働くことができない」という正解例 に対して, RK 群の 9 名とK群の 9 名が「仕事をするこ とができない」という述部や話の内容が正解例とほほ 同じ回答をした。NC 群の 9 名は, 正解例とは内容が異 なる「仕事をし過ぎる」「仕事を失う」「過労死」とい う回答をした。2-6「姉は町で働いていた」という正解 例に対して, RK 群の 12 名, K群の 10 名が「姉が町で 働いている」「姉は町で仕事をしている」等の正解例と 主部, 述部や内容がほほ同じ回答をした。NC 群では, 都会, オフィスで働くという述部と内容が正解例と異
なる回答が 10 名あった。2-7 a「私は歩けない」という 正解例に対して, RK 群の 6 名, R 群の 11 名が「歩く ことができない」「うまく歩けません」などという主 部, 述部や内容が正解例とほぼ同じ回答を示し, NC 群 の 13 名は,「歩かない」「歩くのがいや」等の正解例と 異なる内容の解釈をした。2-8 a「姉が眠りに帰ってく る」という正解例に対し, RK 群の 9 名, K群の 8 名が 「姉が䚻ってくる」「姉が泊まりに来る」などという主 部, 述部や内容が正解例とほほ同じ回答を示し, $\mathrm{NC}$ 群 の 4 名は「姉が寝込んでいて見舞いに人や友人がくる」 等の内容が異なる解釈をした。2-8b「私はうれしい」 
という正解例と同じ回答が， R 群で 19 名と多く, NC 群は 9名だった。2-8c「帰ってしまう」という正解例 に対して, RK 群の 10 名, K群の 11 名, R群の 13 名 がほほ同じ回答を示し, NC 群は 5 名であった。2-8d 「私は悲しかった」という正解例に, R 群の 23 名は「悲 しかった」「さみしい」というほほ同じ回答を示し, NC 群は 11 名であった。2-10a「家族はラジオで敗戦を聞 いた」という正解例に対して, RK 群と K 群では「終戦 の知らせを聞いた」「玉音放送を聞いた」という述部や 文脈上で正解例と同じ意味の回答が 10 名ずつあった。 $\mathrm{NC}$ 群では「ラジオを聞いた」「家族の悲報を聞いた」 という正解例と異なる回答が 11 名あった。

\section{考察}

本研究は, 発信者と初対面かつシンボルの未経験者 が文字を併記したシンボルによるメッセージを理解す るために, 事前に与えられた予備知識が文脈として効 果があるかどうか, どのような文脈が効果的であるか について, 実際のコミュニケーション場面で存在する 多くの文脈や表情や動作などの複数の影響の要素を排 除した実験の条件で検証した。

実験結果を次の 3 項目に分けて，考察する。

\section{1) 文脈効果の有効性と限定性}

Table 2 にある NC 群の 1 項目あたりの平均得点が 示すように, 文脈なしに発信者の意図を正しく理解す るという課題は, 難しいものだった。しかし，4 群を 比べると, 課題 1 と 2 の両方で RK 群と K 群は平均得 点が高い傾向にあり, さらに, Table 3 で示すように, 課題 1 では NC 群とK群間， NC 群と RK 群間で各 3 項目, 課題 2 では NC 群と K 群間, NC 群と RK 群間で 各 6 項目に有意差があることから, 話題のキーワード と発信者に関する情報・受信者との関係が与えられた RK 群と話題のキーワードだけが与えられた K 群の 2 群の文脈がシンボルによるメッセージの理解に効果が あると考えられた。この結果は, 難解なテキストの情 報処理過程において, 事前に与えられた文脈が大きく 影響するという Bransford \& Johnson (1972) の 2 つの 実験の結論を支持した。

しかし, 一方で, 文脈効果の限定性も示唆したと考 えられる。R群に与えられた発信者に関する情報・受 信者との関係の情報は, 課題 2 については $\mathrm{NC}$ 群と 4 項目で有意差があり, 伝達意図を正しく理解するため の文脈として有効であると考えられたが, 課題 1 につ いては, NC 群と 1 項目しか有意差がなく, 文脈として 有効であるとは考えられなかった。このように文脈の
内容によって効果に差が認められた。

また， 1 項目あたりの平均得点が最も高い RK 群に おいても, 課題 1 と 2 の両方で 2 点未満であり (Table 2), 文脈があっても, 主部と述部とメッセージの内容を 十分に理解することは難しい傾向にあると考えられる。 項目別（Figure 1 と 2) に見ると，1-8b，2-1，2-7 b は， 4 群間に有意差がなく，かつ 2 つ文脈が与えられた RK 群の得点が 1 に近かった結果から, 特に文脈が与 えられても文脈の効果がなく解釈が難しかったと考え られる。1-8 b の RK 群の回答では, 1-8 a と合わせて 単文として捉え，「(母は料理が)苦手」「(母は料理するのが) たいへんそう」「(母は料理が)きらい」と，1-8 2つの 項目から構成されたメッセージであるとは理解してい ない回答が 7 名あった。2-7bでも，2-7 a とのつなが りで単文として捉え,「家に(帰ってきませんでした)」「家 に(歩いて誉らなかった)」と，2つの項目とは解釈しない 回答が 6 名あった。2-1の RK 群では [男]のシンボル を「兵隊」と解釈できた回答はなく, 内容の解釈が難 しかった。このように 2 つの項目で構成されるメッ セージと, いくつもの解釈の可能性がある概念を表す 名詞を使用した場合は, 文脈があっても解釈が難しい 傾向にあると考えられる。

一方で文脈が与えられない NC 群でも，1-7や 2-9 のように得点が 2.5 程度あり, 解釈が容易な項目も あった。これらは 1 つの項目から成る単文であり, 文 字で表記されたシンボルの名称通りの意味で解釈でき るメッセージであったことが, 容易さに影響したと考 えられる。

\section{2） K群とR群の文脈の解釈過程と効果}

Table 3 で示された NC 群と有意差がある群は, そ の項目のメッセージを理解するために効果的な情報を 伝えていたと考えられる。課題 1 について, K群の文 脈がメッセージを理解するために効果的であった項目 は 1-1，1-4 a, 1-4 b， R群の文脈が効果的であった項 目は, 1-6 と考えられる。課題 2 について, K群が効果 的であった項目は，2-2，2-4 a, 2-6，2-8 a, 2-10 a, R群が効果的であった項目は, 2-7 a , 2-8 b , 2-8d で あった。そこで, K群と R 群について, それぞれの文 脈が, どのようにメッセージの解読に影響を与えたの かについて分析する。なお， 2-8c は, R と K 群の両方 が効果的であったため分析は省いた。

課題 1 の $\mathrm{K}$ 群の海外からの転校という話題のキー ワードは, 1-1で[家族］ [来る]のシンボルを，「女の 子が家族といっしょに日本に来た」と解釈させ，その ような情報のないR R 群と NC 群は, シンボルの語順通 
りに，[家族］を主語, [来る] を述語に捉え，「家族が 来ます」と回答したと考えられる。1-4 a は，K群の文 脈により, 母語が違う環境におかれてコミュニケー ションの問題をもつ状況にあると想定されて, [話す] [いいえ] のシンボルが「話すことができない」と解 釈されたと考えられる。 R群や NC 群ではそのような 問題を想定しないため,「話をせずに」「しゃべりたく ない」などという自分の意思による否定の意味に解釈 されたと考えられる。1-4 b は，1-4 a の文章と連結し て，K群では「話すことができないので座っていた， 座っているだけです」, R 群では「話をせずに, 座って いなければなりません」という回答が多かったと考え られる。このように，K群の海外からの転校という文 脈は，それに関連するスキーマによって，メッセージ を海外から転校したという特殊な環境に置かれた時の 内容として解釈することを助けた。

$\mathrm{R}$ 群の文脈が効果的であった 1-6では, 11 歳の女の 子という情報が, [少年] [けんか] のシンボルを, 彼 女を主語として,「男の子あるいは少年とけんかをし た」と解釈させ, 発信者の情報を得ていない $\mathrm{K}$ 群や NC 群では, シンボルの並び順通りに「少年たちあるいは 子どもがけんかをしている」という解釈が多くなった と考えられる。このように発信者の情報は 1-6 を発信 者の行動として解釈することを助けたが, 課題 1 の中 の 1 項目だけであり, 十分に効果的であったとは言え なかった。

課題 2 で, R 群が効果的であった 2-7 a では, [歩く] [いいえ]のシンボルを,「歩くことができない」と解 釈させ, 個人情報のないK $\mathrm{K}$ 群と $\mathrm{NC}$ 群では, 「歩いて帰 らない」「歩くのがいや」など本人の意思として解釈さ せたと考えられる。2-8b「うれしい」，2-8d「悲しい」 は，姉が来てくれて㷌ってしまうという状況について， 妹である発信者が肢体不自由で施設入所者であるとい う情報によって, K群や NC 群よりも多くの人に発信 者の気持ちを「うれしい」「悲しい」と解釈させたと考 えられる。このようにR群の発信者の情報が, それに 関連するスキーマを想起させ, 発信者の行動や気持ち を理解するために効果があった。

$\mathrm{K}$ 群の「戦争の思い出」という話題のキーワードが 有効であった 2-2では, 2 名に[男]という主語を戦争 に関連する「兵士」と解釈させ, R 群では発信者と関 係のある「弟」「夫」と解釈させたと考えられる。2-4 a では [仕事] [いいえ] のシンボルを, K群では戦争 中で「仕事ができない」と解釈させ, NC 群では, 現代 の問題として「仕事をし過ぎる」「仕事を失う」と解釈
させたと考えられる。 $\mathrm{R}$ 群の発信者の情報からも「仕 事ができない」と解釈されたが，K群よりも回答例は 少なかった。2-6では, [町] のシンボルを, 戦争中と 考えるK 群は町と捉え， $\mathrm{R}$ 群や $\mathrm{NC}$ 群では現代と想定 するため, 都会と捉える回答があったと考えられる。 2-8 a では, K群は, 戦争中の状況として「姉が家に 帰ってくる」という回答になり, R 群は, 施設入所と いう発信者情報によって「姉が来た」「姉が来てくれる」 という回答が多くなったと考えられる。2-10 a では,

[ラジオ］のシンボルを，K群はラジオで放送された 終戦の知らせや玉音放送という意味で解釈したと考え られる。 R 群は, 施設に入所しているという発信者の 情報が,「ラジオを聞くと家族が恋しい」などの発信者 の気持ちとして解积させ, 情報のない NC 群は, ラジ オで聞いた内容を連想せず，「ラジオを聞いた」と回答 した。このように R 群が発信者の気持ちや状況に関わ る解釈をする傾向があるのに対して, 戦争の思い出と いう文脈が与えられた K 群は, 戦争に関するスキーマ を想起させて, メッセージを戦争の話題に関連させて 解釈することを助けた。

課題 1 でR 群の発信者の情報が十分効果的だとは言 えなかったことについては，発信者の情報として伝え る内容が影響したと考えられる。課題 1 の年齢, 性別, 所属についての情報が, 一般的な事柄であったのに対 して, 課題 2 では, 肢体不自由の施設入所者という特 徵的な事柄を含んでいるため, 本人の気持ちや行動の 解釈に役だったのではないかと考える。課題 1 に関し ても, 発信者がボリビア人で日本人ではないという特 徵を伝えていたら, 理解度が異なったのではないかと 考えられる。このように発信者の情報を有効な文脈に するためには, 本人の特徵的なことを含める必要があ ることが示唆された。

課題 1 と 2 における R 群と K 群の影響の分析から, 本人が自分のしたことや気持ちを伝えるメッセージに は, 基本情報に特徵的な個人情報も加えた発信者の情 報が解釈に効果的であり, 話題とする内容に関連して 述べられる状況や状態については, 話題のキーワード が理解を高めるために有効であったと考えられる。

また， 2 つ文脈の違いによる解釈の差は，どのよ うなスキーマを喚起させるかという違いであることを 示したと考えられる。最近の認知心理学の学説では, 情報を処理する過程では, スキーマが重要な役目を果 たすことが論述され, 入カメッセージを既存の知識で あるスキーマに統合した形で理解しようとする(広瀬, 1999）と考えられている。また, 人間の言語情報の理解 
の過程においても，耳や目から入力された言語情報が， 比較的単純な複数の命題として一時的にワーキングメ モリの中で保持された後, 長期記憶のなかに貯蔵され ている既存の知識によって, 情報を理解するための処 理が活性化されると考えられている (Kellogg, 2003)。本 研究の結果からも難解な情報を理解する場合は, 文脈 が必要なスキーマを活性化させることによって, 正し く理解することが容易になったと考えることが可能で ある。文脈がどのようなスキーマを想起させるかに よって, 文字を併記したシンボルそのものの意味, 主 語の解釉などが異なることが示された。

\section{3 ) 文脈効果の利用と課題}

年度によって担任や担当者が代わり継続したコミュ ニケーション関係をもつことが難しい傾向にある学校 や施設の現実問題に対しては, 発信者が話題にしたい と思っている情報を次の担当者に引き継ぐと, 話題が 共有できるため, 話題に関連して述べられる状況や状 態についての伝達内容は理解しやすくなる。また, 発 信者に関する年齢・性別・所属という基本的な情報に 加えて個人の特徴的な情報を引き継ぐと, 発信者の気

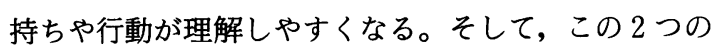
文脈を引き継ぐことが, 最も文脈効果を上げて, コミュ ニケーションが不成立に終わる経験を繰り返さず，発 信者のコミュニケーション意欲を減退させないことに つながる可能性が高いことが示唆された。また, シン ボル使用者が新しいパートナーを作り人間関係を拡げ るためにも，シンボル使用者を知る回りの人が新しい パートナーに，事前にこれらの文脈を伝えるとコミュ ニケーションがとりやすいことを明らかにした。

しかし, 一方で, 文脈効果の限定性も指摘され, 十 分な意思疎通のためには文脈を得ることに加えて他の 方策も併用する必要性が示唆された。その 1 つとして は，項目のつながりが理解できるようなシンボルの接 続詞と，1つのシンボルでいくつかの意味を表さなく ても済むように名詞シンボルを増やす必要があると考

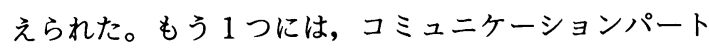
ナーの能力が相互交渉に大きく影響する (Calculator, 1999)ため，パートナーになる可能性がある人たちの能 力の育成に努めることが重要であろう。原（2004）は， コミュニケーションパートナートレーニングが，コ ミュニケーションの成立に大きく影響したと述べてい る。AAC の手法では, コミュニケーションをとるため には複数の非言語手段を併用することが勧められてお り，初めて受信者となるシンボル使用の初心者は，良 いコミュニケーションパートナーや良い支援者になる
ために，文脈を理解しながら，発信者の表情や視線や ジェスチャーなどの表出を受け止めて，意図を解釈し， 応答できる能力を高めることが望まれる。

\section{引用文献}

Bransford, J. D., \& Johnson, M. K. (1972). Contextual prerequisites for understanding : Some investigations of comprehension and recall. Journal of Verbal Learning and Verbal Behav ior, 11, 717-726.

Calculator, S. N. (1999). AAC outcomes for children and youths with severe disabilities: When seeing is believing. Augumentative and Alternative Communication, 15, 4-12.

土井ゆかり (2001). 施設での生活を豊かに 藤澤 和子（編） 視覚シンボルでコミュニケーション 一日本版 PIC 活用編（pp. 47-54）ブレーン出版

藤澤和子 $\quad(2000)$ ． 日本版 PIC シンボルの適用年齢 に関する研究一健常幼児の品詞別理解年齢調査か らの検討一 特殊教育学研究, 38(2), 63-71.（Fujisawa, K. (2000). Development of comprehension of visual symbols in the Pictogram Ideogram Communication, Japanese version : Mental-age-based normative index. Japanese Journal of Special Education, 38(2), 63-71.)

藤澤和子 (2001)。重度言語障害者への日本版 PIC を使用したコミュニケーション支援一脳性マヒ $\mathrm{Y}$ の事例一 発達人間学論叢（大阪教育大学発達人 間学講座)，7，77-89. (Fujisawa，K. (2001). Communication support using PIC Japanese version for person with severe speech disorders : The case study of a cerebral palsied person Y. Hattatsu Ningen Ronsou. Journal of Human Development at Osaka Kyoiku University, 7, 77-89.)

藤澤和子 (2004). コミュニケーション支援用絵記 号の標準化について一意義と課題一 発達人間学 論叢（大阪教育大学発達人間学講座）, 7, 51-59. (Fujisawa, K. (2004). Standardization of pictograms for supporting communication : Significance and problems. Hattatsu Ningen Ronsou. Journal of Human Development at Osaka Kyoiku University, 7, 51-59.)

藤澤和子・井上智義 (2000a)。ことばの壁を越える ための視覚シンボル使用の試み一ボリビア人児童 
の事例研究からの検討一 電子情報通信学会信学 技報, 100, 57-63. (Fujisawa, K., \& Inoue, T. (2000a). Teaching Japanese using PIC symbols : A case study of an elementary school child from Bolivia. Institute of Electronics, Information and Communication Engineers, 100, 57-63.)

藤澤和子・井上智義 $(2000 \mathrm{~b})$. 日本版 PIC 絵単語の 語彙増加とその特徵 電子情報通信学会信学技 報，99，1-8. (Fujisawa，K.，\& Inoue, T. (2000b). How we increased the pictogram vocabulary of Japanese version of Pictogram Ideogram Communication. Institute of Electronics, Information and Communication Engineers, 99, 1-8.)

藤澤和子・井上智義・清水寛之・高橋雅延 （1995）。視 覚シンボルによるコミュニケーションー日本版 PIC ブレーン出版

Glennen, S. L., \& De Coste, D. C. (Eds.) (1997). Handbook of augmentative and alternative communication. San Diego, CA : Singular Publishing Group.

原哲也 (2004). コミュニケーションパートナー トレーニングが脳性麻舫児の AAC 手段の使用と 相互交涉に与える効果 コミュニケーション障害 学, 21, 69-77. (Hara, T. (2004). Effect of communication partner training for AAC : A case study of teacher-student interaction. Japanese Journal of Communication Disorders, 21, 69-77.)

広川律子・吉田くすほみ （1985）。 サウンズアンドシ ンボルズ 南大阪療育園

広瀬雄彦 (1999). 情報の伝達と理解 井上智義 （編） 視聴覚メディアと教育方法（pp. 42-59）
北大路書房

Kellogg, R. T. (2003). Cognitive psychology $\left(2^{\text {nd }}\right.$ ed.). London : Sage Publications.

北神慎司・山縣宏美・室井みや (2002). 視覚シンボ ルの認識容易性に関する実験心理学的検討 日本 教育工学会誌，26，39-44. (Kitagami， S., Yamagata, H., \& Muroi, M. (2002). The psychological study about the recognition of visual symbols. Japan Journal of Educational Technology, 26 (Suppl.), 39-44.)

清田公保・中山典子・藤澤和子・井上智義 （2004）．視 覚シンボルを利用した知的障害児向け電子メール ソフトの開発 電子情報通信学会信学技報, 103, 19-24. (Kiyota, K., Nakayama, N., Fujisawa, K., \& Inoue, T. (2004). Development of the electronic mail system for mentally retarded children using the pictogram and ideogram symbols. Institute of Electronics, Information and Communication Engineers, 103, 19-24.)

清水寛之（編著）（2003）. 視覚シンボルの心理学 ブレーン出版

塚原三津子 (2001). [うれしい] [悲しい]を使用し て, Yes・Noの意思表示を明確にすることで “や りとり”関係が育った $\mathrm{N}$ ゃん 藤澤和子（編） 視覚シンボルでコミュニケーションー日本版 PIC 活用編（pp. 20-30） ブレーン出版

\section{謝辞}

本論文は, 2005 年度同志社大学大学院文学研究科教 育学専攻に提出した博士論文の一部を加筆修正したも のです。本論文を作成するにあたり，ご指導を賜りま した同志社大学大学院井上智義先生に心から感謝申し 上げます。

(2006.3.10 受稿, ’08.3.7 受理) 


\section{Appendix}

材料のシンボルのメッセージと正解例

課題 1

$1-1$

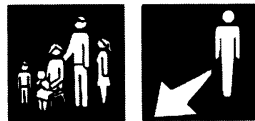

家族

$1-2$

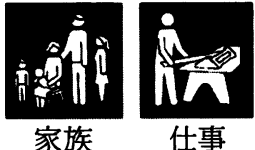

1-3

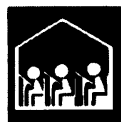

学校

$1-4 \mathrm{a}$

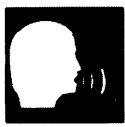

話

$1-4 \mathrm{~b}$

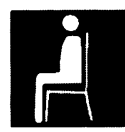

いいえ

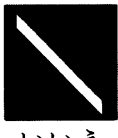

座る

$1-5$

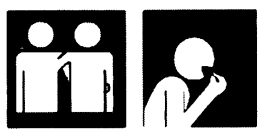

友達

食べる

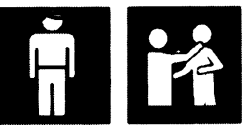

1-6

少年

けんか

1-7

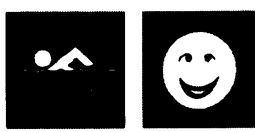

泳ぐ 幸せ

$1-8 \mathrm{a}$

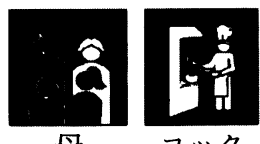

母

$1-8 b$

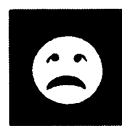

悲しい

$1-9 a$
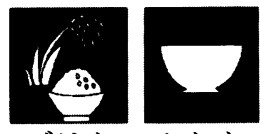

ごはん おわん
私は家族で日本に来た。

家族は日本で働いている。

私は学校に行っている。

私は日本語が話せない。

（私は）座っていた。

私は友達と食事やかけっこをしている。

私は男の子とけんかをした。

私は泳ぐことが好きです。

母は日本料理がうまく作れない。

（母は）悲しそうだ。

ごはんはおわんに入れる。 
$1-9 \mathrm{~b}$

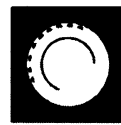

お血

$1-10$

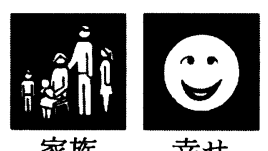

家族

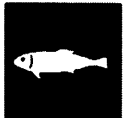

魚

幸せ
おさらには魚を入れる。

家族は幸せです。

父は兵隊さんと魚を食べたり飲んだりした。

兵隊さんは家で寝ていた。

兵隊さんは病気だった。

兵隊さんは働くことができなかった。

亡くなることは悲しかった。

山と海の近くにこのような家があった。

姉は町で働いていた。

私は歩けない。

（私は）家にいた。 


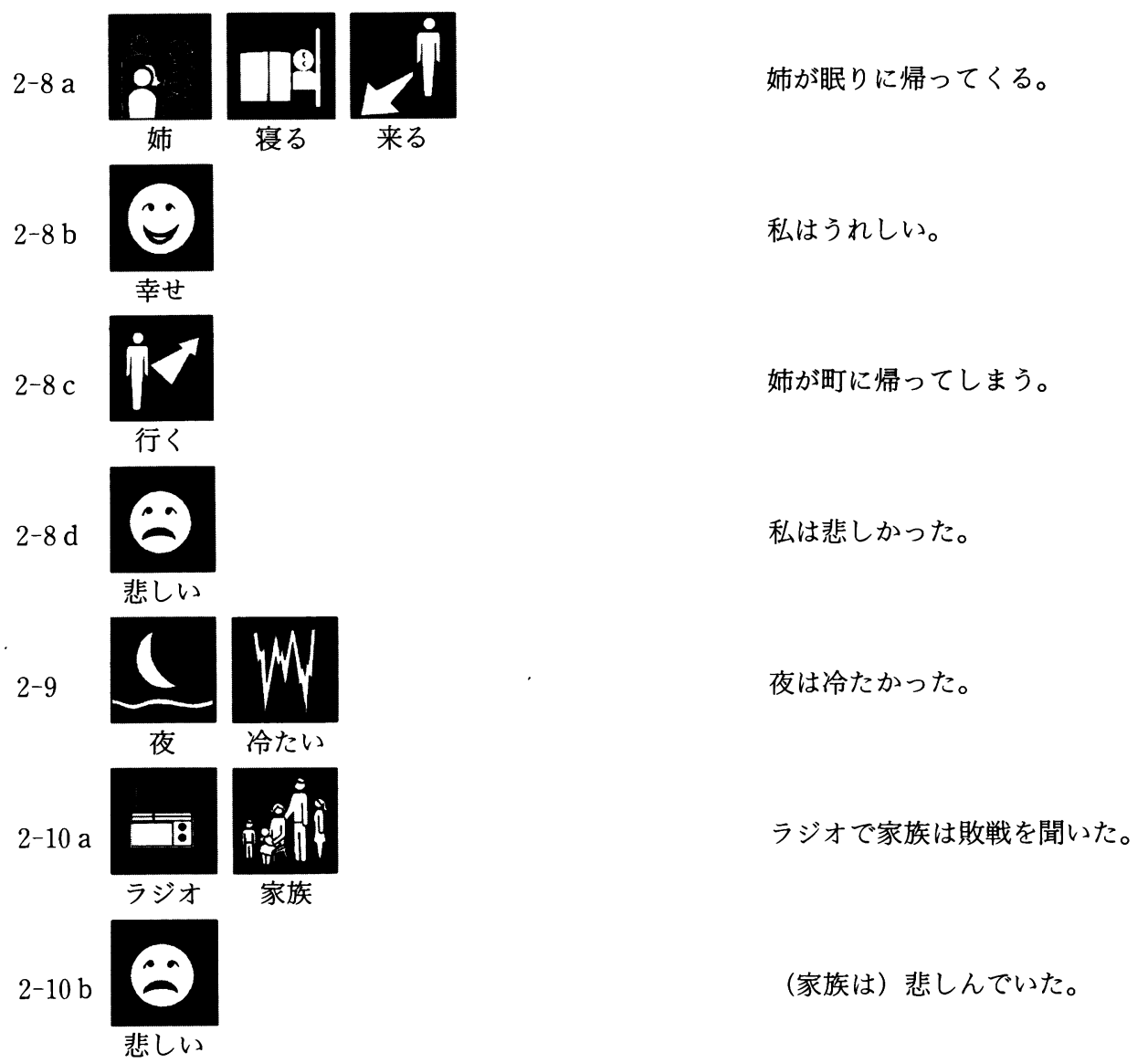




\section{Effects of Context on Understanding the Meaning of Messages Written by Using Pictograms and Japanese Characters}

KAZUKo FUJISAWA (KYOTO DEAF SCHOOL) JAPANESE JOURNAL OF EDUCATIONAL PSYCHOLOGY, 2008, 56, 303-317

The purpose of the present experiment was to investigate how context or prior knowledge given to participants in advance would influence the correctness of their comprehension of messages that consisted of pictograms written with Japanese characters. University students $(N=96)$ were required to interpret 2 messages comprised entirely of pictograms accompanied by Japanese characters. The 4 conditions were as follows : (a) no context was given in advance (NC), (b) information was provided about the sender and the sender's relation to the receiver (R), (c) a keyword for the topic was provided (K), and (d) all the above information was provided in advance (RK). The results showed that the context given in advance to the groups getting either a keyword or all the information played an influential role in the participants' understanding of the sender's intentions in the pictogram messages. This suggests that appropriate schemas were activated by this prior knowledge, and that that in turn may have facilitated the appropriate interpretation of the messages.

Key Words : pictograms with Japanese characters, context, schema, communication, communicative intention 